\title{
Rice False Smut Disease at Different Flowering Times
}

\author{
Bodrun Nessa, ${ }^{2 *}$, Moin U. Salam³, A.H.M. Mahfuzul Haque1, Jiban K. Biswas², \\ M. Abdul Latif², M. Ansar Ali², Tahmid H. Ansari², Montasir Ahmed², Nargis Parvin², \\ M. Zakaria Ibne Baki², Subrima Islam², M. Sirajul Islam² and Jean Galloway ${ }^{3}$
}

\begin{abstract}
Rice false smut (RFSm) has lately been recognized as an emerging disease worldwide. Its alarming prevalence in Bangladesh in the transplant Aman rice in the last three years has been widely reported. However, there is no effective control measure against the disease in this country. We hypothesized that manipulation of flowering time in aman rice may avoid RFSm incidence. A two-year study (2014 and 2015) during T. Aman season using the widely regarded RFSm-prone variety, BRRI dhan49, across a range of flowering regime from mid-July to mid-January, demonstrated lower disease incidence in earlier (till midOctober) and later (after mid-November) part. The highest incidence of the disease was recorded when the crop flowered on 9 and 5 November in 2014 and 2015, respectively. The disease was recorded on ratoons. The peak of the infection recorded on ratoons when flowered on 7 November. To the best of our knowledge, worldwide, this is the first record of the disease on ratoons. Rainfall did not influence the disease. The relationship between the disease incidence and relative humidity and sunshine hours were significant. Avoiding flowering time during mid-October to mid-November through planting time adjustment appeared as an effective practice to escape rice false smut disease incidence in Aman season.
\end{abstract}

Keywords: Disease incidence, false smut, flowering time, maximum temperature, minimum temperature, rain-days, ratoon, relative humidity, rice, sunshine hours, transplanting time, Ustilaginoidea virens, Villosiclava virens

\section{INTRODUCTION}

The status of rice false smut (RFSm) as an emerging fungal disease (anamorph: Ustilaginoidea virens (Cooke) Takah.; teleomorph Villosiclava virens (Nakata) E. Tanaka and C. Tanaka) of rice (Oryza sativa L.) has been recognized worldwide (Atia, 2004; Brooks et al., 2009; Ashizawa et al., 2010; Li et al., 2013; Singh et al., 2014; Nessa et al., 2015a). The disease is a serious concern to the farmers of Bangladesh during T. Aman season (rainfed rice), due to its epidemic outbreak especially on a popular variety 'BRRI dhan49'. RFSm is an inflorescence disease. The symptom of the disease only appears after rice crops flower. On the other hand, recent findings indicate that the infection is likely to onset one to three weeks earlier to appearance of smut balls ( $\mathrm{Li}$ et al., 2013; Jia et al., 2014).

While few studies were conducted relating weather and spore release (Sreeramulu et al., 1966), the potential association of weather variables during infection stage to incidence of RFSm has not been well documented.

The management of the disease is not well recognized as its salient epidemiological features under field conditions are still unknown (Nessa et al., 2015b, Tanaka, 2015). As Jecmen (2014) points out, "Understanding how to manage RFSm (rice false smut) has been difficult because the literature is fragmented, unclear or at times, even contradictory.

Many questions relevant to the integrated management of RFSm using cultural practices, fungicide applications and deployed resistance remain unaddressed". Among the cultural management options, a number of studies have attempted to control RFSm through manipulation of transplanting time in China (Liang et al., 2014, Egypt (Atia, 2004), India (Dodan and Singh, 1994), Nigeria (Ahonsi et al., 2000) and in the USA (Brooks et al., 2009). However, a similar study has not yet been conducted in Bangladesh.

\footnotetext{
${ }^{1}$ Department of Plant Pathology and Seed Science, Sylhet Agricultural University, Sylhet-3100, Bangladesh; ${ }^{2}$ Bangladesh Rice Research Institute (BRRI), Gazipur 1701, Bangladesh; and 3Department of Agriculture and Food Western Australia (DAFWA), South Perth, WA6151, Australia. Corresponding author's E-mail: runu.brri@yahoo.com
} 
Although the disease infects main crop (primary planting), recent observation shows, for the first time in the world, that it also affects ratoons (regenerated tillers from harvested main crop) (Nessa et al., 2015b). However, further studies are required to re-establish the findings and to investigate whether the pattern of the disease incidence in ratoons is similar to that in the main crop.

With the above background, the present study was undertaken to investigate whether false smut epidemic on susceptible rice variety can be escaped with changing flowering times of the crop by varying the transplanting time. The study also aimed to identify major weather parameters influencing the disease.

\section{MATERIALS AND METHODS}

\section{Experimental site study period}

The experiments were conducted in the research farm of the Bangladesh Rice Research

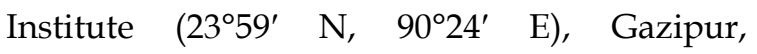
Bangladesh during T. Aman season of 2014 and 2015. This farm has built up an intensive riceecosystem over the last 40 years while growing rice in as many as three seasons annually in about 88 fields spread over 35 hectare area. It is situated at about $35 \mathrm{~m}$ above the mean sea level and has a subtropical climate strongly influenced by the south-western monsoon (Nessa et al., 2015a).

\section{Experimental design and treatments}

Effect of the varying flowering times on natural incidence of RFSm was investigated in repeated experiments laid out following a randomised complete block (RCB) design with 10 replications in 2014 and three replications in 2015. To generate wide range of flowering time, seven different transplanting times (15 June, 30 June, 15 July, 30 July, 14 August, 29 August and 13 September) of BRRI dhan49 (a highly susceptible variety) served as treatments in 2014 trial. However, 12 different transplanting times (19 May, 4 June, 19 June, 4 July, 20 July, 4 August, 19 August, 5 September, 19 September, 5 October, 19 October an 5 November) of the same variety were used in the 2015 trial. The individual plot was $2.5 \mathrm{~m} \times 2.5 \mathrm{~m}$ in 2014, and $30.5 \mathrm{~m} \times 2.5 \mathrm{~m}$ in 2015 .

\section{Transplanting and crop management}

Thirty-day-old seedlings were hand transplanted at two or three seedlings per hill, maintaining a spacing of $20 \mathrm{~cm} \times 20 \mathrm{~cm}$. The crops were fertilized with recommended doses of nitrogen (N) (200 kg ha-1 as urea), phosphorus (P) (63 kg ha-1 as triple super phosphate), potassium (K) (84 $\mathrm{kg} \mathrm{ha}^{-1}$ as muriate of potash) and sulphur (S) (56 kg ha-1 as gypsum) (BRRI, 2013). Nitrogen was top dressed in three equal splits: 20, 35 and 50 days after transplanting (DAT), whereas $\mathrm{P}, \mathrm{K}$, and $\mathrm{S}$ were applied once, during final land preparation. The crops received moisture predominantly through monsoonal rains, but supplemented by irrigation water to maintain a water level of 2 to $3 \mathrm{~cm}$. Management of the crops included manual weed control twice, at 30 and 45 DAT. No insecticide, fungicide or other chemical were used for pest and disease control. No artificial inoculation was conducted to modify natural disease pressure.

\section{Ratooning}

For ratooning, the hills in the main crops were harvested at maturity by manually cutting the tillers at $40-60 \mathrm{~cm}$ height. No additional crop management practice was applied for ratoons. In the 2014 trial, ratoons voluntarily generated in two plots transplanted on 15 June, and nine plots transplanted on 15 July. However, in 2015 trial, ratoons generated in all the plots transplanted on 19 May and 19 June.

\section{Trial assessment}

Dates of $50 \%$ flowering were recorded for each transplanting time on main crops and ratoons. In addition, the progression of newly formed smut balls on ratoons was recorded by at three days interval during 15 August 2015 to 15 January 2016. The trials were assessed for disease incidence by counting smut ball(s) bearing panicles (diseased panicles) and total 
panicles in each plot at the late ripening stage. The same was done for ratoons.

\section{Data presentation and analysis}

The disease incidence (DI) on main crops and ratoons was calculated using the following equation

$\mathrm{DI}=[($ Number of diseased panicles $) /$ (total number of panicles)] $\times 100$ Eq. (1)

All the DI values were summarized against 50\% flowering time of main crops and the ratoons. The DI data were analyzed and compared at the 95\% confidence interval (CI) using an in-built formula in MS Excel 2010 (Nessa et al. 2015b).

Data on five weather parameters, maximum temperature $\left({ }^{\circ} \mathrm{C}\right)$, minimum temperature $\left({ }^{\circ} \mathrm{C}\right)$, relative humidity (\%), sunshine hours and raindays (number), were summarized for 5-days prior to 15 days (Jia et al., 2014) of each record of $50 \%$ flowering to find any association of weather to the level of disease incidence. The daily weather data for 2014 and 2015 gathered from the Physiology Division of BRRI were used for this purpose.

In order to relate DI with weather parameters, the range of DI in both years was categorized into three sections of flowering window: "early" (5 August to 12 October), "mid" (17 October to 23 November) and "late" (4 December to 28 December). The association of five weather parameters to DI in the three defined periods of flowering window was measured through correlation. The significant weather parameters from correlation study were subjected to regression analysis relating DI.

\section{RESULTS}

In 2015, the rice false smut (RFSm) disease initiated (DI $(\%)=0.07 \pm 0.01$, is $95 \%$ confidence interval) when the crop flowered on 5 August (Fig. 1). The level of the disease remained low (DI $\leq 0.47 \%$ ) in the crops flowering before midOctober. The RFSm reached the peak (DI $(\%)=$ $2.40 \pm 0.30$ ) on 5 November and ceased on 28 December flowering crops. The data on initiation and cessation time of the disease was not available for 2014 season. However, like 2015, the disease level was low (DI 0.47 to $0.49 \%$ ) in the crops flowering till mid-October. The RFSm reached the peak (DI $(\%)=2.45 \pm 0.67$ ) on the crop flowered on 9 November.

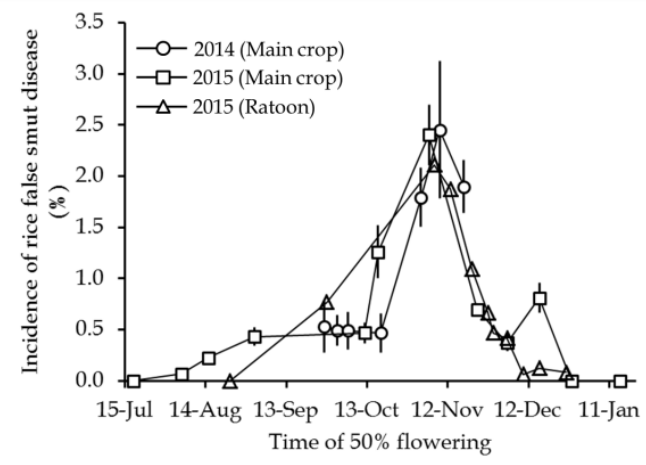

Fig. 1. Incidence of rice false smut disease across the flowering window rice during T. Aman seasons of 2014 and 2015. "Jul", "Aug", "Sep", "Oct", "Nov", "Dec" and "Jan" denotes for July, August, September, October, November, December and January, respectively. Vertical bars indicate $95 \%$ confidence intervals.

When measured the disease progression in relation to time of $50 \%$ flowering of ratoons, it was observed that the first appearance of RFSm appeared on ratoons that flowered on 28 September (Fig. 1). The peak of the disease incidence $(2.11 \%)$ occurred on ratoons that flowered on 7 November. The disease incidence was very low on the ratoons that flowered after 10 December.

Table 1 presents the disease status and weather parameters influencing the disease infection. The table shows that the disease in the "midflowering-window" was significantly higher (1.47 \pm 0.54 is $95 \%$ confidence interval) than "early-flowering-window" $(0.39 \pm 0.13)$ or "lateflowering-window" (0.19 \pm 0.37$)$. Corresponding weather parameters during the probable infection of the disease did not show significant correlation between the disease incidence and maximum temperature or minimum temperature, or rain-days. The relationship between the disease incidence and relative humidity or sunshine hours were significant (Table 1). 
Table 1. The incidence of rice false smut disease (DI, \%) in BRRI dhan49 and weather variables in three sections of flowering window during T. Aman seasons of 2014 and 2015. Also shown, the correlations between five weather variables and the DIs. The \pm indicates $95 \%$ confidence interval, " $n s$ " denotes for not significant and "*" for significant at $P<0.05$

\begin{tabular}{lrrrrr}
\hline Disease status, or & \multicolumn{3}{c}{ Flowering window } & & $\begin{array}{r}\text { Correlation coefficient }(\mathrm{r}) \\
(n=18)\end{array}$ \\
\cline { 2 - 4 } Weather parameters & \multicolumn{1}{c}{ Early } & \multicolumn{1}{c}{ Mid } & \multicolumn{1}{c}{ Late } & \\
\hline Disease incidence $(\%)$ & $0.39 \pm 0.13$ & $1.47 \pm 0.54$ & $0.19 \pm 0.37$ & + \\
Maximum temperature $\left({ }^{\circ} \mathrm{C}\right)$ & $32.2 \pm 1.1$ & $32.0 \pm 1.2$ & $28.3 \pm 1.5$ & $+0.38^{\mathrm{ns}}$ \\
Minimum temperature $\left({ }^{\circ} \mathrm{C}\right)$ & $24.4 \pm 0.8$ & $20.2 \pm 2.6$ & $15.2 \pm 3.2$ & $-0.09^{\mathrm{ns}}$ \\
Relative humidity $(\%)$ & $84.0 \pm 3.9$ & $72.0 \pm 3.4$ & $83.9 \pm 2.9$ & $-0.62^{*}$ \\
Sunshine hours & $4.6 \pm 1.4$ & $7.6 \pm 0.6$ & $3.7 \pm 0.7$ & \\
Rain-days (number) & $2.3 \pm 1.0$ & $0.1 \pm 0.3$ & $0.0 \pm 0.0$ & & $-0.62^{*}$ \\
\hline
\end{tabular}

Figure 2 presents further analysis of the two significant weather parameters - sunshine hours and relative humidity - and disease incidence across the whole range of flowering window of BRRI dhan49 during 2015 T. Aman season. The figure shows a positive significant response (expressed in regression) of the disease incidence (DI) to the sunshine hours $\left(P<0.05, R^{2}=0.46\right)$. As indicated earlier, the relationship between relative humidity and DI was also significant but negative. The relationship between sunshine hour and relative humidity, on the other hand, had been strongly negative $\left(P<0.05, R^{2}=0.75\right)$.

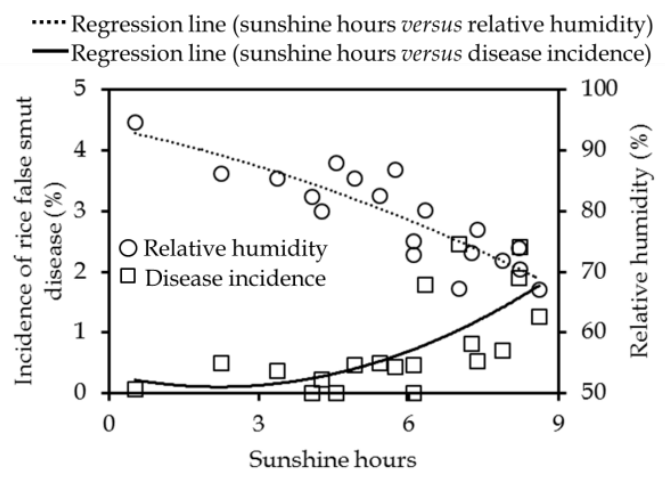

Fig. 2. Regression between sunshine hours and disease incidence $(\mathrm{Y}=0.3001-0.179 \mathrm{X}+$ $\left.0.0408 X^{2}, R^{2}=0.46, n=18\right)$, and between sunshine hours and relative humidity $(\mathrm{Y}=$ $93.792-1.7356 X-0.1351 X^{2}, R^{2}=0.75, n=18$ ) across the whole range of flowering window of BRRI dhan49 during 2015 T. Aman season.

\section{DISCUSSION}

In this study, the incidence of rice false smut (RFSm) disease was estimated across a range of flowering regimes of a T. Aman rice variety in 2014 and 2015 by setting the transplanting time accordingly. With this, the start and cessation of the timing of the disease on T. Aman rice have been recognized, which have not been reported so far in Bangladesh. Our results show early flowering crops (thereby planted early) had significantly lower disease incidence compared to later flowering crops. In his early work in Japan, Ikegami (1960) observed that RFSm disease on 20 May sown crop was almost 2-fold compared to the crop sown on 1 May. In India, similar findings have been reported in the 1980s and 1990s (Narinder and Singh, 1984; Singh and Kang, 1987; Dodan and Singh, 1994). Thus, manipulation of planting time could be a way to control this disease (Parsons et al., 2001; Ahonsi and Adeoti, 2002; Brooks et al., 2011). It is suggested that escaping false smut epidemic by planting the early maturating group of cultivars (Zhou et al., 2010) as late maturing varieties show higher rates of infection (Liang et al., 2014).

Our findings also suggest that the disease incidence declines after reaching at the peak during 2 to 9 November. The timing of this peak was consistent from 2015 observations in main crops and ratoons, 2014 crops, and observations in another variety (BR11) from different experiments (S Islam, MS Islam and M Ahmed, BRRI, 2015, unpublished data). The 
level of the disease towards the tail-end of flowering regime was very similar to earlypart of flowering window. Most of the literature hardly mentioned the disease at the tail-end of flowering window. In an early work, Raw (1964) noted that mid- duration crop had the highest incidence than short or long duration crop. Raw's finding is a subjective agreement to our findings.

While there is no disagreement that "early" planting can be a mean of avoiding the major incidence of RFSm disease, the term "early" itself may be confusing to many aspects. For example, how early this "early" should be? Besides, farmers use varieties of different growth durations. In that case, the timing of "early" planting of a long duration variety will vary with the timing of "early" planting of a medium or short duration variety. To avoid these confusions, we have worked out that the chance of the high disease incidence may be avoided if the crop does not flower during mid-October to mid-November.

Many reports associate high cloud cover (Ho, 1979; Ahonsi, 1995), frequent rainfall (Ho, 1979; Ahonsi, 1995; Cartwright et al., 2002; Fan et al., 2014) and high relative humidity (Raw, 1964; Ahonsi, 1995; Biswas, 2001) to high disease incidence. However, we did not find any positive relationship between rainfall and disease incidence. For example, in our studies, rainfall did not influence the disease; analysis rather showed negative correlation between rain-days and DI; under rainless conditions, the DI varied between 0 to $2.5 \%$. It may be noted that the $2.5 \%$ was the highest disease recorded during the two experiment years. A number of findings agree with our results. Raw (1964) observed that actual precipitation has less effect on the incidence of the disease. Dodan and Singh (1996) reported that low rainfall favoring the disease. In spore-trap experiments, it has been reported that the continuous and heavy rain can significantly decrease or even completely disappear RFSm spore-load (Sreeramulu and Vittal, 1966). With no rain at all, Devi and Singh (2007) found the highest RFSm spore concentration on air. In our studies, rainfall did not influence relative humidity (RH) or sunshine hours (SSH). Under rainless conditions, the $\mathrm{RH}$ varied between 67.0 to $85.4 \%$, whereas SSH varied between 3.4 to 8.6 hours.

In this study, SSH and RH influenced the disease, SSH positively and RH negatively. The association between $\mathrm{SSH}$ and $\mathrm{RH}$ was very strong. The question may arise, which is the prime factor for the disease? Is it the SSH or the RH or the both? The RH may not be the sole answer, as high disease occurred at lower $\mathrm{RH}$ and low disease occurred at higher RH. It is likely that higher SSH in association with relatively lower RH (possible threshold: 70$80 \%$ ) encouraged good crop growth as well as RFSm disease development.

\section{CONCLUSION}

This study finds that the major incidence of rice false smut disease during T. Aman can be avoided by planting rice varieties in such a way that the crops do not flower during midOctober to mid-November. However, this information may be variety and site specific and, therefore, required to be validated using other rice varieties across the agro-ecological regions of Bangladesh. Furthermore, both qualitative and quantitative relationships between two weather variables (relative humidity and sunshine hours) and disease incidence need to be established through further studies.

\section{ACKNOWLEDGEMENTS}

This study is a part of first author's on-going $\mathrm{PhD}$ research. The Bangladesh Agricultural Research Council (BARC) offered a $\mathrm{PhD}$ fellowship, and the Bangladesh Rice Research Institute (BRRI) granted study leave and provided with research facilities to run the $\mathrm{PhD}$ programme - BN deeply acknowledges both BARC and BRRI for that. MUS thanks the Department of Agriculture and Food Western Australia (DAFWA) for facilitating a semisabbatical arrangement to be involved in the 
study, and BRRI for hosting him. BN is grateful to the Plant Pathology Division of BRRI for assistance in data collection especially through Scientific Assistant Mohammed Nizamul Karim. JG acknowledges DAFWA for providing opportunity to contribute to this project.

\section{CONCLUSION}

This study finds that the major incidence of rice false smut disease during T. Aman can be avoided by planting rice varieties in such a way that the crops do not flower during midOctober to mid-November. However, this information may be variety and site specific and, therefore, required to be validated using other rice varieties across the agro-ecological regions of Bangladesh. Furthermore, both qualitative and quantitative relationships between two weather variables (relative humidity and sunshine hours) and disease incidence need to be established through further studies.

\section{ACKNOWLEDGEMENTS}

This study is a part of first author's on-going $\mathrm{PhD}$ research. The Bangladesh Agricultural Research Council (BARC) offered a PhD fellowship, and the Bangladesh Rice Research Institute (BRRI) granted study leave and provided with research facilities to run the PhD programme - BN deeply acknowledges both BARC and BRRI for that. MUS thanks the Department of Agriculture and Food Western Australia (DAFWA) for facilitating a semisabbatical arrangement to be involved in the study, and BRRI for hosting him. BN is grateful to the Plant Pathology Division of BRRI for assistance in data collection especially through Scientific Assistant Mohammed NizamulKarim. JG acknowledges DAFWA for providing opportunity to contribute to this project.

\section{REFERENCE}

Ahonsi, M O. 1995. Studies on the false smut of rice, Oryzasativa L., induced by Ustilaginoidea virens (Cke.) Tak. MS Thesis, Department of crop protection, Faculty of Agriculture, Ahmadu Bello University, Zaria, Nigeria.95 pp.

Ahonsi, M O, A A Adeoti, I D Erinle, T A Alegbejo, B N Singh and A A Sy. 2000. Effect of variety and sowing date on false smut incidence in upland rice in Edo State, Nigeria. IRRI Notes 25: 14.

Ahonsi, M O and A A Adeoti. 2002. False smut on upland rice in eight rice producing locations of Edo State, Nigeria. J. Sus. Agric. 20: 81-94.

Ashizawa T, M Takahashi, J Moriwaki and K Hirayae. 2010. Quantification of the rice false smut pathogen Ustilaginoidea virens from soil in Japan using real-time PCR. Eur J Plant Pathol 128:221-232.

Atia, M M M. 2004. Rice false smut (Ustilaginoidea virens) in Egypt. J. Plant Dis. Protection. 111: 71-82.

Biswas, A. 2001. False smut disease of rice: a review. Environ. Biol. 19:67-83

Brooks, S A, M M Anders and K M Yeater. 2009. Effect of cultural management practices on the severity of false smut and kernel smut of rice. Plant Dis. 93: 1202-1208.

Brooks, S A, M M Anders and K M Yeater. 2011. Influences from long-term crop rotation, soil tillage, and fertility on the severity of rice grain smuts. Plant Dis. 95:990-996.

BRRI. 2013. Adhunik Dhaner Chash (Modern Rice Cultivation). Bangladesh Rice Research Institute, Gazipur 1701, Bangladesh (in Bangla).

Cartwright, R D, C E Parsons, B J Dodgen, F N Lee and E A Sutton. 2002. Rice disease monitoring and onfarm variety evaluation in Arkansas. In: Norman RJ, Meullenet JF, editors. B.R. Wells Rice Research Series 2001.Uni. Ark. Agric. Exp. Stn. Res. Series. 495:138-147.

Devi, T K and N I Singh. 2007. Aerobiology and epidemiology and false smut of rice by Ustilaginoidea virens, (Syn. Clavicepsoryzae sataivae) in Thoubal district, Manipur.J. Mycopathol. Res. 45(1): 107-108.

Dodan, D S and R Singh. 1994. Effect of planting time on the incidence of blast and false smut of rice in Haryana. Indian Phytopathol. 47:185-187.

Dodan, D S and R Singh. 1996. False smut of rice: present status. Agric. Res. 17:227-240.

Fan, J, X Y Guo, F Huang, Y Li and YF Liu, L Li, Y-J Xu, JQ Zhao, HXiong, J-J Yu and W Wang. 2014. Epiphytic colonization of Ustilaginoidea virens on biotic and abiotic surfaces implies the widespread presence of primary inoculum for rice false smut disease. Plant Pathol. 63: 937945.

Ho, B L. 1979. Incidence of false smut disease of rice in relation to rice variety and climatic factors in Malaysia. MARDI Res. Bull. 7: 89-95.

Ikegami, H. 1960. Studies on the false smut of rice, IV.Infection of the false smut due to inoculation with chlamydospores and ascospores at booting stage of rice plants. Res. Bull. Faculty Agriculture Gifu Univ. 12: 45-51.

Jecmen, A C. 2014. Biology and Control of Rice False Smut Caused by Ustilaginoidea virens (Teleomorph Villosiclava virens).MS Thesis, Department of Plant Pathology, University of Arkansas, USA. $188 \mathrm{pp}$.

Jia, Q, B Lv, M Guo, C Luo, L Zheng, T Hsiang and J Huang. 2014. Effect of rice growth stage, temperature, relative humidity and wetness duration on infection of rice panicles by 
Villosiclava virens. Eur. J. Plant Pathol. 138 : 763773.

Li, W, L Li, AFeng, X Zhu and J Li. 2013. Rice false smut fungus, Ustilaginoidea virens, inhibits pollen germination and degrades the integuments of rice ovule. Am. J. Plant Sci. 4: 2295-2304.

Liang, Y, X-M Zhang, D-Q Li, F Huang, P-S Hu and Y-L Peng. 2014. Integrated approach to control false smut in hybrid rice in Sichuan Province, China. Rice Sci. 21: 354-360.

Narinder, S and M S Singh. 1989. Effect of different levels of nitrogen and dates of transplanting on the incidence of false smut of paddy in Punjab. Indian J. Ecol. 14: 164-167.

Nessa, B, M U Salam, A H M M Haque, J K Biswas, W J MacLeod, M A Ali, K P Halder and J Galloway. 2015a. FLYER: A simple yet robust model for estimating yield loss from rice false smut disease (Ustilaginoidea virens). Am. J. Agric. Biol. Sci. 10: 41-54.

Nessa, B, M U Salam, A H M M Haque, J K Biswas, M S Kabir, W J MacLeod, M D'Antuono, H N Barman, M A Latif and J Galloway. 2015b. Spatial pattern of natural spread of rice false smut (Ustilaginoidea virens) disease in fields. Am. J. Agric. Biol. Sci. 10: 63-73.

Parsons, C E, E A Sutton, B J Dodgen, R M Chlapecka, BThiesse, $\mathrm{R}$ Thompson and $\mathrm{R} \mathrm{D}$ Cartwright.
2001. Management of false smut of rice in Arkansas. Res. Ser.Ark. Agric. Exp.Stn. 485: 142148.

Raw, K M. 1964. Environmental conditions and false smut incidence in rice. Indian Phytopath. 17: 110-114.

Singh, N, and M S Kang. 1987. Effect of different levels of nitrogen and dates of transplanting on the incidence of false smut of paddy in Punjab. Indian J. Eco. 14:164-167.

Singh S, A A Lal, S Simon, A Singh, R Taduman, Kamaluddeen, A A David. 2014. Survey of false smut (Ustilaginoidea virens) of rice (Oryzasativa L.) in selected districts of Utter Pradesh, India. The Bioscan 9: 389-392.

Sreeramulu, T and B P R Vittal. 1966. Periodicity in the airborne spores of the rice false smut fungus, Ustilaginoidea virens. Trans. Br. Mycol. Soc. 49: 443-449.

Tanaka, E. 2015. Life cycle and infection route of rice false smut fungus in paddy field. JSM Mycotoxins. 65:39-43.

Zhou, Y L, J L Xu, X W Xie, X Q Gao, J Wang andZ K Li. 2010. Effects of maturity group of cultivar, pathogen amount and sowing date on the severity of rice false smut in the field. ActaPhytophyl. Sin. 37: 97-103 (in Chinese with English abstract). 